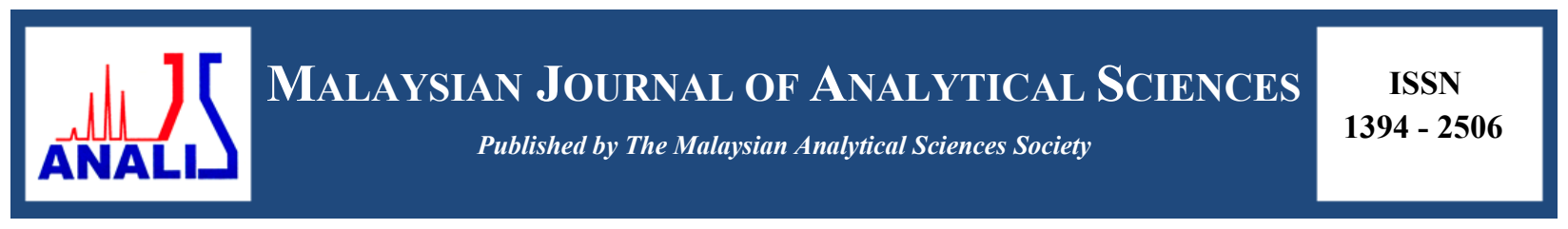

\title{
ISOLATION OF OLIGOSTILBENES FROM Shorea bracteolate
}

\author{
(Pemisahan Oligostilbene daripada Shorea bracteolate) \\ Norhazana Norizan ${ }^{1}$, Norizan Ahmat $^{1,2} *$, Yana Maulana ${ }^{3}$, Zurina Shameeri ${ }^{1}$ \\ ${ }^{1}$ Faculty of Applied Sciences, \\ Universiti Teknologi MARA, 40450 Shah Alam, Selangor, Malaysia \\ ${ }^{2}$ Atta ur Rahman Institute for Natural Product Discovery \\ Universiti Teknologi MARA, Puncak Alam Campus, 42300 Bandar Puncak Alam, Selangor, Malaysia \\ ${ }^{3}$ Department of Chemistry, \\ Institut Teknologi Bandung, Jalan Ganesha 10, Bandung 40132, Indonesia \\ *Corresponding author: noriz118@salam.uitm.edu.my
}

Received: 24 February 2015; Accepted: 27 October 2015

\begin{abstract}
Phytochemical investigation has been carried out on the stem bark of Shorea bracteolate. Three known oligomeric stilbene compounds, namely vaticanol A (1), stepnophyllol C (2) and hopeaphenol A (3) were isolated from the acetone extract of the plant. The structure of the isolated compounds were determined based on the analysis of spectroscopic data, including Nucleus Magnetic Resonance (NMR), Ultra Violet (UV), Infrared (IR) and comparison with literature.
\end{abstract}

Keywords: $\varepsilon$-viniferin, hopeaphenol, Vaticanol A, Stepnophyllol C, Shorea bracteolate, dipterocarpaceae

\begin{abstract}
Abstrak
Kajian fitokimia telah dilakukan ke atas bahagian kulit batang Shorea bracteolate. Tiga sebatian oligomerik stilbene iaitu vatikanol A (1), stepnofilol C (2) dan hopeafenol A (3) telah diasingkan daripada ekstrak aseton S. bracteolate. Struktur sebatian-sebatian ini telah ditentukan menggunakan analisis data spektroskopi termasuk Resonans Magnet Nukleus (NMR), Ultra Violet (UV), Infra merah (IR), dan perbandingan dengan literatur.
\end{abstract}

Kata kunci: $\varepsilon$-viniferin, hopeaphenol, Vaticanol A, Stepnofilol C, Shorea bracteolate, dipterocarpacea

\section{Introduction}

Shorea is a subfamily of Dipterocarpaceae family. A large number of stilbene derivatives have been isolated from plants belonging to the families of the Vitaceae, Leguminosae and Dipterocarpacea [1]. Plants of the largest subfamily, Dipterocarpoideae, are the sources of resveratrol oligomers (oligostilbenoids), sesquiterpenes, and triterpenes [2]. Until now, the chemistry of Dipterocarpaceae is relatively less known. This is because the early research on Dipterocarpaceae was mainly focused on the chemical compounds of their resins such as terpenoid, sesquiterpenoid and triterpenoid. In the last two decades, the phytochemical research on Dipterocarpaceae has shifted rapidly. This is due to the fact that oligomeric resveratrol compounds have been found to be the main polyphenols. They include stilbene dimers, trimers, tetramers, hexamers, heptamers and octamers with various molecular framework resulting from different oxidative condensations of revesratrol monomers. These compound also show a variety of important bioactivities such as anti inflammatory, antibacterial, antifungal, cytotoxicity, chemopreventive and hepatoprotective. They also inibit topoisomerase II, gastic ATPase and $5 \alpha$-reductase reaction [3]. 
Shorea bracteolate called white meranti is widely distributed in Sumatera, Peninsular Malaysia, Indonesia and Singapura. The tree grows up to $50 \mathrm{~m}$ in height and the timber is light hardwood. This paper reports the isolation and structure determination of a stilbene dimer, a stilbene trimer and a stilbene tetramer form the plant.

\section{General experimental procedure}

\section{Materials and Methods}

${ }^{1} \mathrm{H}$ and ${ }^{13} \mathrm{C}$ spectra were recorded in acetone-D on Bruker 300 Ultrashield NMR spectrometer measured at 300 and $125 \mathrm{MHz}$. IR spectrums and UV spectra were recorded on the Perkin Elmer spectrum on FT-IR spectrometer and Shimadzu UV-vis 160i instruments, respectively. Melting point was measured by Fisher Johns. Optical rotations were determined using a Perkin-Elmer 341 polarimeter in MeOH. Vacuum liquid chromatography (VLC) was carried out using Si-gel Merck 60 GF254 (230 - 400 mesh), while column chromatography (CC) was used Si-gel Merck $60(200-400 \mathrm{mesh})$ and TLC analysis on precoated Si-gel Merck Kieselgel 60 F254 0.25mm, 20 x $20 \mathrm{~cm}$ plates.

\section{Plant material}

The stem bark of Shorea bracteolate was collected in 2009 and a voucher specimen had been deposited at the UPM.

\section{Extraction and isolation procedure}

The stem bark of $S$. bracteolate was dried and cut into small pieces and ground to powder about $1 \mathrm{~mm}$ mesh size using a grinder. The sample was extracted with acetone and the extract was evaporated in vacuo at $40{ }^{\circ} \mathrm{C}$ to yield a crude extract. The crude extract was fractionated using (VLC) to give 6 fractions. Fraction 3 (F3) was subjected to multiple radial chromatography (RC) to afford Compound 1. Fraction 4 (F4) was subjected to VLC using a series of increasing polarity solvent from $40 \%$ hexane $/ 60 \%$ ethyl acetate to $90 \%$ ethyl acetate $/ 10 \%$ methanol to give 5 fractions. Subfraction F43 was resubjected again to VLC to give 12 fractions. Similar TLC profile were pooled together to give 4 fractions. Subfraction F432 was then subjected to radial chromatography (RC) and CC to give Compound 2 [C: A: M (9:0.5:0.5)]. F44 was subjected to RC and PTLC to give Compound 3 [C: M (9:1)].

\section{Results and Discussion}

Investigation on the tree bark of Shorea bracteolate have resulted in the isolation of three oligostilbenoid compounds which successfully characterized as vaticanol A (1), stepnophyllol C (2) and hopeaphenol A (3). Compound 1 was obtained as a yellow powder. The ${ }^{1} \mathrm{H}-\mathrm{NMR}$ spectrum showed three sets of ortho- coupled aromatic protons. They were assignable to three 4-hydroxyphenyl groups at $7.28\left(2 \mathrm{H}, \mathrm{d}, \mathrm{J}=8.4, \mathrm{H}_{2 \mathrm{a}, 6 \mathrm{a}}\right), 6.83(2 \mathrm{H}$, dd, $\left.\mathrm{J}=8.4, \mathrm{H}_{3 \mathrm{a}, 5 \mathrm{a}}\right), 7.07\left(2 \mathrm{H}, \mathrm{d}, \mathrm{J}=8.4, \mathrm{H}_{2 \mathrm{~b}, 6 \mathrm{~b}}\right), 6.60\left(2 \mathrm{H}, \mathrm{dd}, \mathrm{J}=8.7, \mathrm{H}_{3 \mathrm{~b}, 5 \mathrm{~b}}\right), 6.55\left(2 \mathrm{H}, \mathrm{dd}, \mathrm{J}=8.7, \mathrm{H}_{2 \mathrm{c}, 6 \mathrm{c}}\right)$ and $6.37(2 \mathrm{H}, \mathrm{dd}, 8.4$,

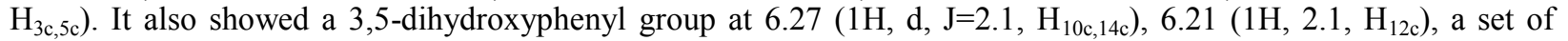
meta- coupled aromatic protons at $6.09\left(1 \mathrm{H}, \mathrm{d}, 2.4, \mathrm{H}_{12 \mathrm{a}}\right), 6.48\left(1 \mathrm{H}, \mathrm{d}, 2.4, \mathrm{H}_{14 \mathrm{a}}\right)$, aromatic proton of a pentasubstituted benzene ring at $6.22\left(\mathrm{br}, \mathrm{s}, \mathrm{H}_{12 \mathrm{~b}}\right)$, four unit of aliphatic methine protons coupled at $5.17\left(\mathrm{br}, \mathrm{s}, \mathrm{H}_{7 \mathrm{~b}}\right), 4.52$ (br , s , $\left.\mathrm{H}_{8 \mathrm{~b}}\right), 3.64\left(1 \mathrm{H}, \mathrm{d}, 7.8, \mathrm{H}_{7 \mathrm{c}}\right), 4.19\left(\mathrm{br}, \mathrm{s}, \mathrm{H}_{8 \mathrm{c}}\right.$ ), a set of aliphatic protons at 6.18(br, s, H7a) and $4.52\left(\mathrm{br}, \mathrm{s}, \mathrm{H}_{8 \mathrm{a}}\right.$ ). From these characteristics, it was suggested that the compound 1 is vaticanol A [4]. Figure 1 show the structure of vaticanol A.

Compound 2 was obtained as brownish powder. The ${ }^{1} \mathrm{H}$ NMR spectrum showed the presence of two sets of orthocoupled aromatic proton at $\delta 7.12\left(2 \mathrm{H}, \mathrm{d}, \mathrm{J}=15 \mathrm{~Hz}, \mathrm{H}_{2(6) \mathrm{a}}\right), 6.76\left(2 \mathrm{H}, \mathrm{d}, \mathrm{J}=15 \mathrm{~Hz}, \mathrm{H}_{3(5) \mathrm{a}}\right), 6.76\left(2 \mathrm{H}, \mathrm{d}, \mathrm{J}=15 \mathrm{~Hz}, \mathrm{H}_{2(6) \mathrm{b}}\right)$, $6.58\left(2 \mathrm{H}, \mathrm{d}, \mathrm{J}=15 \mathrm{~Hz}, \mathrm{H}_{3(5) \mathrm{b}}\right)$, a 3,5-dihydroxyphenyl group $\delta 6.29\left(1 \mathrm{H}, \mathrm{br} \mathrm{s}, \mathrm{H}_{10 \mathrm{a}}\right), 6.32\left(1 \mathrm{H}, \mathrm{s}, \mathrm{H}_{12 \mathrm{a}}\right)$, a singlet aromatic proton $6.21\left(1 \mathrm{H}, \mathrm{s}, \mathrm{H}_{12 \mathrm{~b}}\right)$, two broad aliphatic protons $\delta 4.30\left(1 \mathrm{H}, \mathrm{br} \mathrm{s}, \mathrm{H}_{7 \mathrm{~b}}\right), 3.98\left(1 \mathrm{H}, \mathrm{br} \mathrm{s}, \mathrm{H}_{8 \mathrm{~b}}\right)$, two mutually coupled aromatic aliphatic hydrogens $5.32\left(1 \mathrm{H}, \mathrm{d}, \mathrm{J}=5 \mathrm{~Hz}, \mathrm{H}_{7 \mathrm{a}}\right)$ and $4.32\left(1 \mathrm{H}, \mathrm{s}, \mathrm{H}_{8 \mathrm{a}}\right)$. From these characteristics, it was suggested that the compound 2 is stepnophyllols $C$ [5]. Figure 2 shown the structure of stepnophyllols C. 


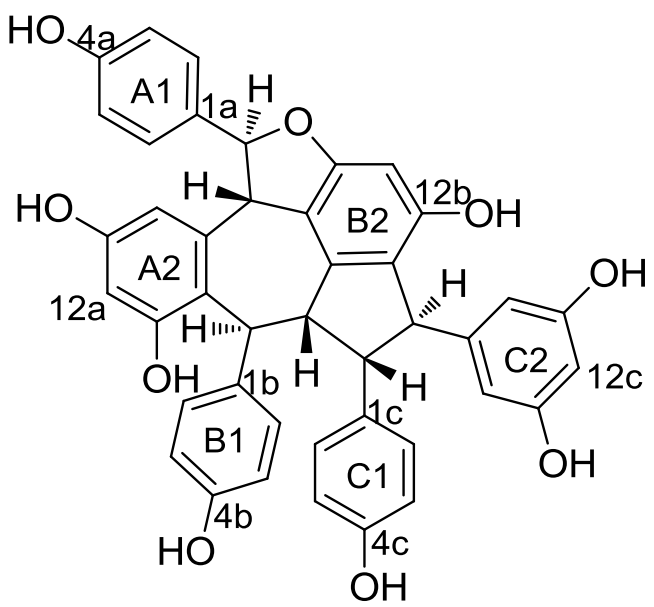

Figure 1. Structure of Vaticanol A

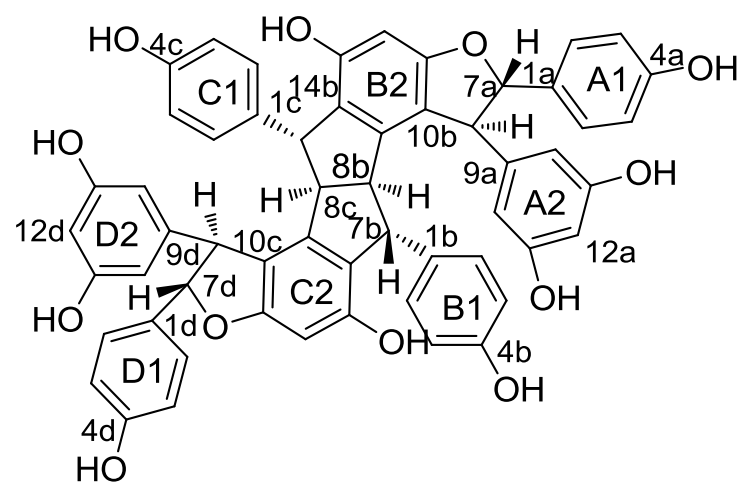

Figure 2. Structure of Stepnophyllols C

Compound 3 was obtained as a yellowish amorphous powder. The ${ }^{1} \mathrm{H}$ NMR spectrum showed the presence of eight ortho- coupled aromatic proton. They were assignable to four $1,4-$ disubstituted aromatic ring $\delta 7.25(2 \mathrm{H}, \mathrm{d}$, $\left.\mathrm{J}=8.5 \mathrm{~Hz}, \mathrm{H}_{2(6) \mathrm{a})}\right), 6.84\left(2 \mathrm{H}, \mathrm{d}, \mathrm{J}=8.5 \mathrm{~Hz}, \mathrm{H}_{3(5) \mathrm{a}}\right), 7.52\left(2 \mathrm{H}, \mathrm{d}, \mathrm{J}=8.5 \mathrm{~Hz}, \mathrm{H}_{2(6) \mathrm{a}}\right), 6.93\left(2 \mathrm{H}, \mathrm{dd}, \mathrm{J}=8.5 \mathrm{~Hz}, \mathrm{H}_{2(6) \mathrm{b}}, 3(5) \mathrm{a}^{\mathrm{a}}\right)$, $6.56\left(2 \mathrm{H}, \mathrm{d}, \mathrm{J}=8.5 \mathrm{~Hz}, \mathrm{H}_{3(5) b}\right), 6.32\left(2 \mathrm{H}, \mathrm{m}, \mathrm{H}_{2(6) \mathrm{b}}, 3(5) \mathrm{b}^{\mathrm{b}}\right)$. Futher analysis of the ${ }^{1} \mathrm{H}$ NMR spectrum revealed a four set of 1,2,3,5 tetrasubstituted aromatic ring, $6.33\left(1 \mathrm{H}, \mathrm{m}, \mathrm{H}_{12 \mathrm{a}}\right), 6.22\left(1 \mathrm{H}, \mathrm{s}, \mathrm{H}_{14 \mathrm{a}}\right), 6.38\left(1 \mathrm{H}, \mathrm{m}, \mathrm{H}_{12 \mathrm{a}^{\mathrm{a}}}\right), 6.40\left(1 \mathrm{H}, \mathrm{s}, \mathrm{H}_{14 \mathrm{a}^{\mathrm{a}}}\right)$, $6.05\left(1 \mathrm{H}, \mathrm{d}, \mathrm{J}=2.1 \mathrm{~Hz}, \mathrm{H}_{12 \mathrm{~b}}\right), 5.90\left(1 \mathrm{H}, \mathrm{m}, \mathrm{H}_{14 \mathrm{~b}, 12 \mathrm{~b}}\right), 5.01(1 \mathrm{H}, \mathrm{d}, \mathrm{J}=2.1)$, a sequence of two vicinal methine doublets $5.83(1 \mathrm{H}, \mathrm{d}, \mathrm{J}=13 \mathrm{~Hz}, \mathrm{H} 7 \mathrm{a}), 4.41(1 \mathrm{H}, \mathrm{d}, \mathrm{J}=13 \mathrm{~Hz}, \mathrm{H} 8 \mathrm{a}), 5.73\left(1 \mathrm{H}, \mathrm{d}, \mathrm{J}=8.5 \mathrm{~Hz}, \mathrm{H} 7 \mathrm{a}^{\prime}\right), 5.43\left(1 \mathrm{H}, \mathrm{d}, \mathrm{J}=8.5 \mathrm{~Hz}, \mathrm{H} 8 \mathrm{a}^{\prime}\right)$ and four contiguous methine multiplets $5.06(1 \mathrm{H}, \mathrm{d}, \mathrm{J}=5.0 \mathrm{~Hz}, \mathrm{H} 7 \mathrm{~b}), 4.30(1 \mathrm{H}, \mathrm{dd}, \mathrm{J}=5.0 \mathrm{~Hz}, \mathrm{H} 8 \mathrm{~b}), 4.73(1 \mathrm{H}, \mathrm{d}, \mathrm{J}=4.5 \mathrm{~Hz}$, $\left.\mathrm{H} 7 \mathrm{~b}^{\prime}\right), 2.65\left(1 \mathrm{H}, \mathrm{dd}, \mathrm{J}=5, \mathrm{H} 8 \mathrm{~b}^{\prime}\right)$. From these characteristics, it was suggested that the compound 3 is hopeaphenol A [6]. Figure 3 shown the structure of hopeaphenol A.

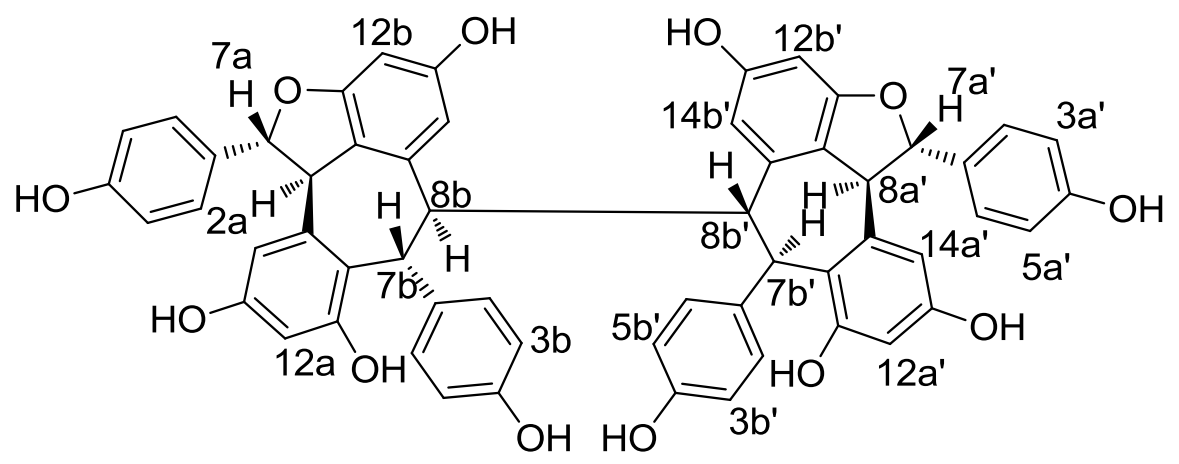

Figure 3. Structure of Hopeaphenol A

\section{Conclusion}

Three oligostilbenes, Vaticanol A (1), Stepnophyllol C (2) and hopeaphenol A (3), were successfully isolated from the acetone extract of the stem bark of Shorea bracelate. 


\section{References}

1. Sotheeswaran, S and Pasupathy, V. (1993). Distribution of resveratrol oligomers in plants. Phytochemistry, 32: 1083-1092

2. Seo, E. K. and Douglas, K. A. (2000). Bioactive constituents of the family Dipterocarpaceae. In: Atta-urRahman (ed) studies in natural products chemistry. Elsevier, 23: $531-561$.

3. Hakim, E. H. (2002). Oligostilbenoid dari tumbuh - tumbuhan Dipterocarpaceae. Bulletin of the Indonesia Society of Natural Products Chemistry, 2(1): $1-19$.

4. Tanaka, T., Ito, T., Nakaya, K., Iunuma, M. and Riswan, S. (2000). Oligostilbenoids in stem of Vatica rassak. Phytochemistry, 54: $63-69$.

5. Masayoshi, O. Toshiyuki, T., Munekazu, I., Charles, L. and Burandt, Jr. (1998). Phenolic compounds isolated from the roots of Sophora stenophylia. Chemical and Pharmaceutical Bulletin, 46(4): 663 -668.

6. Joanna, R., Zgoda-Pols., A., Freyer, J. L., Killmer, B. J. and Porter, R. (2002). Antimicrobial resveratrol tetramers from the stem bark of Vatica oblongifolia ssp.oblongifolia. Journal of Natural Product, 65: 1554 1559 . 